\title{
METODE MULTINOMIAL NAÏVE BAYES UNTUK KLASIFIKASI ARTIKEL ONLINE TENTANG GEMPA DI INDONESIA
}

\author{
(Multinomial Naïve Bayes Method for Classification of Online Article About \\ Earthquake in Indonesia)
}

\author{
Alif Sabrani", I Gede Putu Wirarama Wedashwara W., Fitri Bimantoro \\ Program Studi Teknik Informatika, Fakultas Teknik, Universitas Mataram \\ Jl. Majapahit 62, Mataram, Lombok NTB, INDONESIA \\ Email: alifsabrani@gmail.com, [wirarama, bimo]@unram.ac.id
}

\begin{abstract}
Artikel online tentang gempa bumi dapat dikelompokan ke dalam kategori ekonomi, kesehatan, dan pariwisata. Pengelompokan artikel dalam jumlah besar dapat menguras waktu dan tenaga apabila dilakukan secara manual. Text classification dapat membantu proses klasifikasi artikel ini. Pada penelitian ini, dilakukan pengujian pada performa dari metode probabilistik multinomial Naïve Bayes dalam mengelompokan artikel online tentang gempa bumi di Indonesia. Pembobotan dilakukan dengan menggunakan teknik TF-IDF. Pengujian dilakukan dengan 2 jenis feature yaitu unigram dan bigram, serta penggabungan dari keduanya. Selain itu, pengujian juga dilakukan dengan menghilangkan stemming dan stopwords removal dari tahap preprocessing. F-measure tertinggi yang didapatkan adalah sebesar $95.20 \%$ yaitu pada skenario pengujian dengan menggabungkan feature unigram dan bigram serta melewati tahap stemming dan stopwords removal pada preprocessing.
\end{abstract}

Keywords: Gempa, Artikel Online, Klasifikasi Teks, TF-IDF, Preprocessing, Multinomial Naïve Baye

*Penulis Korespondensi

\section{Pendahuluan}

Secara geologi, Indonesia berada di pertemuan tiga lempeng utama dunia, yaitu Eurasia, Indoaustralia dan Pasifik. Selain itu, Indonesia juga dikenal berada di Cincin Api Pasifik (Ring of Fire) yaitu daerah "tapal kuda" sepanjang $40.000 \mathrm{~km}$ yang sering mengalami gempa bumi dan letusan gunung berapi yang mengelilingi cekungan Samudra Pasifik. Sekitar 90\% dari gempa bumi yang terjadi dan $81 \%$ dari gempa bumi terbesar terjadi di sepanjang Cincin Api ini. Menurut Dr. Daryono, kepala bidang informasi gempa bumi dan peringatan dini tsunami Badan Meteorologi, Klimatologi, dan Geofisika (BMKG), kondisi ini menyebabkan gempa bumi sering terjadi di Indonesia [1].

Terdapat begitu banyak artikel online yang berhubungan dengan gempa bumi di Indonesia yang tersebar di berbagai website. Artikel online pasca gempa dapat berupa kondisi, dampak, maupun aktivitas yang dilakukan di lokasi terjadinya gempa dan dapat dikelompokan ke dalam kategori ekonomi, kesehatan, atau pariwisata. Artikel yang telah dikelompokan dapat membantu untuk memudahkan pembaca dalam mencari informasi.

Pengelompokan artikel dalam jumlah besar dapat menguras waktu dan tenaga apabila dilakukan secara manual. Untuk mempermudah proses pengelompokan ini, diperlukan suatu teknik yang tepat. Teknik yang digunakan untuk klasifikasi dokumen secara otomatis oleh komputer dikenal dengan istilah text classification atau klasifikasi teks [2]. Metode yang dapat digunakan dalam klasifikasi teks adalah metode probabilistik Naïve Bayes. Metode Naïve Bayes terbukti dapat memberikan hasil yang cukup memuaskan ketika digunakan untuk klasifikasi teks [3]. Salah satu model dari Naïve Bayes yang sering digunakan dalam klasifikasi teks adalah multinomial Naïve Bayes [4].

Pada Bagian 2, dibahas uraian-uraian pustaka terbaru yang berkaitan dengan topik artikel. Bagian 3 memuat penjelasan tentang tahapan proses penelitian dengan urutan logis untuk mendapatkan hasil penelitian sesuai dengan harapan. Bagian 4 berisi hasil dan pembahasan penelitian. Dan Bagian 5 berisi pernyataan atas temuan yang dihasilkan dari penelitian dan pernyataan jawaban atas masalah di ingin diselesaikan beserta rencana penelitian di masa mendatang.

\section{Tinjauan PUSTAKa}

Telah dilakukan penelitian untuk mengklasifikasikan pengaduan dan pelaporan masyarakat menggunakan metode multinomial Naïve Bayes [2]. Metode multinomial Naïve Bayes dipilih karena dikenal memiliki 
tingkat akurasi yang tinggi dengan perhitungan sederhana. Dataset yang digunakan pada penelitian ini adalah sebanyak 113 pelaporan. Data dikelompokkan menjadi 3 kelompok yaitu Informasi, Kamtibnas, dan Tindak Pidana. Penelitian yang dilakukan menghasilkan rata-rata akurasi yang tinggi, yaitu recall $93 \%$, precission $90 \%$,dan $f$-measure $92 \%$.

Dilakukan juga penelitian untuk menguji akurasi metode multinomial Naïve Bayes dalam mengelompokkan pesan di ruang percakapan maya dengan [5]. Pesan dikategorikan menjadi 5 kategori yaitu Dalam himpunan, Luar himpunan, Berita duka, Ulang tahun, dan Percakapan lainnya. Hasil yang didapatkan cukup baik dengan F-measure mencapai 90,57\% untuk kategori Dalam himpunan.

Penelitian untuk membandingkan metode multinomial Naïve Bayes dan $k$-nearest neighbor dalam pengelompokan jurnal juga telah dilakukan [6]. Metode multinomial Naïve Bayes dipilih karena hanya memerlukan sejumlah kecil data latih untuk menentukan parameter mean dan varians dari variabel yang diperlukan untuk klasifikasi. Terdapat 4 kategori jurnal yaitu Pendidikan Ekonomi, Pendidikan Bisnis dan Manajemen, Akuntansi Aktual, dan Ekonomi Bisnis. Jumlah data yang digunakan adalah 40 jurnal yang dibagi masing-masing 10 jurnal per kategori. Hasil yang didapatkan menunjukkan metode Naïve Bayes memiliki kinerja yang lebih baik dengan tingkat akurasi 70\%, sedangkan metode $k$-nearest neighbor memiliki tingkat akurasi yang cukup rendah yaitu $40 \%$.

Penelitian untuk mengklasifikasikan dokumen bahasa Bali menggunakan metode Naïve Bayes dengan model multinomial juga telah dilakukan sebelumnya [7]. Metode multinomial Naïve Bayes sering digunakan dalam penelitian tentang klasifikasi teks karena kesederhanaan dan efektivitasnya yang menggunakan ide dasar probabilitas gabungan dari kata-kata dan kategori untuk memperkirakan probabilitas kategori pada suatu dokumen. Setelah dilakukan preprocessing pada dokumen, dilakukan pula seleksi fitur dengan metode information gain. Dokumen dikelompokkan ke dalam kategori seni budaya dan upacara, dengan jumlah data sejumlah 100 dokumen untuk masingmasing kategori. Penelitian menghasilkan nilai rata-rata akurasi dari 10 fold cross validation sebesar 95,22\%.

Dilakukan penelitian tentang klasifikasi konten $e$ government dengan Naïve Bayes classifier menggunakan pembobotan TF-IDF (term frequencyinverse document frequency) [8]. Metode ini dipilih karena memiliki kinerja yang baik terhadap pengklasifikasian data dokumen yang mengandung angka maupun teks. Dokumen diklasifikasikan ke dalam kategori ekonomi dan politik. Penelitian menghasilkan akurasi yang cukup baik yaitu sebesar $85 \%$.

Telah dilakukan pula penelitian tentang sentiment analisys di jejaring sosial Twitter menggunakan algoritma naïve Bayes dengan seleksi fitur mutual information [9]. Metode ini dipilih karena sederhana, memiliki kecepatan yang cukup tinggi, dan menghasilkan akurasi yang baik dalam sentiment analysis. Data yang digunakan adalah sejumlah 500 tweet tentang pariwisata Lombok. Data dikelompokan ke dalam 2 kategori yaitu sentimen positif dan sentimen negatif. Akurasi yang didapatkan melalui pengujian 10fold cross validation adalah $96.2 \%$ tanpa menggunakan seleksi fitur mutual information dan $97.9 \%$ dengan menggunakan seleksi fitur mutual information.

Telah dilakukan perbandingan terhadap beberapa jenis multinomial naïve Bayes dalam mengelompokan dokumen [10]. Dataset yang digunakan dalam penilitian ini adalah 20 newsgroups, industry sector, WebKB, dan Reuters-21578. Dataset tersebut merupakan dataset yang sering digunakan dalam penilitian tentang klasifikasi teks. Penilitian membuktikan bahwa modifikasi transformed weightnormalized complement naïve Bayes (TWNBC) tidak diperlukan untuk mendapatkan hasil yang optimal untuk beberapa dataset. Akan tetapi, penggunaan TFIDF dalam pembobotan kata terbukti dapat meningkatkan akurasi secara signifikan pada sebagian besar dataset. Selain itu, penggunaan normalisasi panjang dokumen dapat mengurangi akurasi dari pembobotan dengan TF-IDF.

Berdasarkan berbagai penelitian yang telah dijelaskan sebelumnya, dapat disimpulkan bahwa metode multinomial naïve Bayes serta metode TF-IDF memiliki hasil yang baik ketika digunakan untuk mengelompokan artikel. Oleh karena itu, penelitian untuk klasifikasi artikel online tentang gempa di Indonesia dapat dilakukan dengan menggunakan kedua metode tersebut.

\subsection{Text Mining}

Text mining merupakan teori tentang pengolahan kumpulan teks dengan tujuan untuk mengetahui dan mengekstrak informasi bermanfaat dari kumpulan teks tersebut. Informasi didapatkan dengan cara identifikasi dan eksplorasi pola yang menarik dari sumber data. Text mining merupakan bidang khusus dari data mining dimana data yang digunakan adalah data tekstual yang tidak terstruktur [8]. Bagian - bagian dari text mining meliputi classification (klasifikasi), clustering, dan association [3]. 


\subsection{Klasifikasi Teks}

Klasifikasi teks merupakan salah satu aplikasi dari text mining. Klasifikasi teks adalah proses pengelompokan teks berdasarkan kata, frase, atau kombinasinya untuk menentukan kategori yang telah ditetapkan sebelumnya (supervised learning) [2].

\subsection{Text Preprocessing}

Text preprocessing merupakan proses untuk mentransformasikan teks ke dalam kumpulan kata. Teks merupakan data yang tidak terstruktur, yang mana cukup sulit untuk diproses dengan komputer. Operasi numerik pun tidak dapat diaplikasikan pada data teks. Oleh karena itu, perlu dilakukan preprocessing pada teks untuk mendapatkan data yang dapat diolah menggunakan komputer. Terdapat 3 langkah mendasar yang dilakukan dalam text preprocessing, yaitu tokenization, stemming, dan stopword removal [3].

\subsubsection{Tokenization}

Tokenization adalah proses untuk memotong teks menjadi kata / token yang dipisahkan oleh spasi atau tanda baca. Proses tokenization menerima teks sebagai input dan menghasilkan kumpulan token sebagai output. Selanjutnya, token yang mengandung karakter spesial atau angka akan dihilangkan, lalu token akan diubah menjadi lowercase [3].

\subsubsection{Stemming}

Proses selanjutnya dalam text preprocessing adalah stemming. Pada tahap ini, token yang didapatkan dari proses tokenization diubah menjadi bentuk dasarnya. Proses stemming biasanya dilakukan pada kata benda, kata kerja, dan kata sifat [3].

\subsubsection{Stop-word removal}

Pada proses stop-word removal, dilakukan penghapusan stop word dari daftar token atau kata yang sudah diproses dengan tahap stemming. Stop word merupakan kata yang tidak berhubungan dengan konteks dari teks, sehingga perlu dihilangkan untuk meningkatkan efisiensi dari proses training atau klasifikasi [3]. Contoh dari stop word dalam bahasa Indonesia adalah "di" dan "ke". Kata - kata tersebut tidak dapat mewakili konteks dari dokumen karena terdapat pada hampir seluruh dokumen.

\subsection{Multinomial Naïve Bayes Classifier}

Naïve Bayes merupakan salah metode pembelajaran mesin probabilistik. Seperti namanya, metode ini mengasumsikan bahwa setiap atribut dari data tidak bergantung satu sama lain. Pada dasarnya, asumsi bahwa setiap kata tidak bergantung satu dengan yang lain pada metode Naïve Bayes ini berlawanan dengan keadaan sebenarnya. Hal ini dikarenakan suatu dokumen atau teks perlu memiliki kata yang saling berhubungan agar dokumen tersebut memiliki makna. Akan tetapi, metode ini terbukti mampu memberikan hasil yang cukup memuaskan apabila diterapkan di bidang klasifikasi teks [3].

Salah satu model dari Naïve Bayes yang sering digunakan dalam klasifikasi teks adalah multinomial Naïve Bayes [4]. Multinomial Naïve Bayes merupakan metode supervised learning, sehingga setiap data perlu diberikan label sebelum dilakukan training. Probabilitas suatu dokumen $d$ berada di kelas $c$ dapat dihitung menggunakan Persamaan (1) [4].

$$
P(c \mid d) \propto P(c) \prod_{k=1}^{n} P\left(t_{k} \mid c\right)
$$

dimana :

$P(c \mid d) \quad$ : Probabilitas dokumen d berada di kelas c

$P(c) \quad$ : Prior probability suatu dokumen berada di kelas c

$\left\{t_{1}, t_{1}, t_{1}, \ldots, t_{n}\right\}$ :Token dalam dokumen $\mathrm{d}$ yang merupakan bagian dari vocabulary dengan jumlah $\mathrm{n}$

$P\left(t_{k} \mid c\right) \quad:$ Probabilitas bersyarat term $t_{k}$ berada di dokumen pada kelas c

Klasifikasi dokumen bertujuan untuk menentukan kelas terbaik untuk suatu dokumen. Kelas terbaik dalam klasifikasi Naïve Bayes ditentukan dengan mencari maximum a posteriori (MAP) kelas $c_{\text {map }}$ melalui Persamaan (2).

$$
c_{\text {map }}=\underset{c \in C}{\arg \max } \hat{P}(c) \prod_{k=1}^{n} \hat{P}\left(t_{k} \mid c\right)
$$

$P$ ditulis dengan $\hat{P}$ karena nilai sebenarnya dari $P(c \mid d)$ dan $P\left(t_{k} \mid c\right)$ belum diketahui, yang akan dihitung pada saat proses training [4].

Pada Persamaan (2), terdapat banyak probabilitas bersyarat yang dikalikan. Hal ini dapat menyebabkan floating point underflow. Karena itu, proses perhitungan akan lebih baik apabila dilakukan penjumlahan pada logaritma dari probabilitas. Kelas dengan logaritma dari probabilitas tertinggi merupakan kelas dengan probabilitas terbaik untuk dokumen; $\log (x y)=\log (x)+\log (y)$. Persamaan (2) yang menggunakan logaritma dari probabilitas dapat dinyatakan dalam Persamaan (3) [4].

$$
c_{\text {map }}=\underset{c \in C}{\arg \max }\left[\log \hat{P}(c)+\sum_{1 \leq \mathrm{k} \leq \mathrm{n}} \log \hat{P}\left(t_{k} \mid c\right)\right]
$$


$\hat{P}(c)$ dan $\hat{P}\left(t_{k} \mid c\right)$ didapatkan dengan menghitung maximum likelihood, yang merupakan frekuensi relatif dari parameter. Untuk prior, dapat digunakan Persamaan (4).

$$
\hat{P}(c)=\frac{N_{c}}{N}
$$

dimana :

$\hat{P}(c) \quad$ : Prior probability suatu dokumen berada di kelas c

$N_{c} \quad$ : Jumlah dokumen dengan kelas c

$N \quad$ : Jumlah seluruh dokumen

$\hat{P}(t \mid c)$ merupakan probabilitas frekuensi relatif term $t$ dalam dokumen berada di kelas $c$, yang dapat dihitung menggunakan Persamaan (5).

$$
\hat{P}(t \mid c)=\frac{T_{c t}}{\sum_{t \prime \in V} T_{c t \prime}}
$$

dimana :

$\begin{array}{ll}\hat{P}(t \mid c) & \begin{array}{l}\text { : Probabilitas bersyarat term } \mathrm{t} \text { berada } \\ \text { di dokumen pada kelas c }\end{array} \\ T_{c t} & \begin{array}{l}\text { : Jumlah kemunculan term } \mathrm{t} \text { pada } \\ \text { dokumen dengan kategori c }\end{array} \\ \sum_{t^{\prime} \in V} T_{c t^{\prime}} & \begin{array}{l}\text { : Jumlah frekuensi seluruh term pada } \\ \text { kelas c }\end{array}\end{array}$

Perhitungan maximum likelihood memiliki kelemahan, yaitu suatu kata dalam kelas yang tidak terlihat pada data training akan memiliki nilai 0 . Hal ini menyebabkan perhitungan $P(c \mid d)$ menghasilkan nilai 0 , karena setiap bilangan yang dikalikan dengan 0 akan menghasilkan 0 . Untuk mengatasi masalah ini, diterapkan teknik add-one atau Laplace smoothing, sehingga Persamaan (5) berubah menjadi Persamaan (6).

$$
\hat{P}(t \mid c)=\frac{T_{c t+1}}{\sum_{t \prime}\left(T_{c t^{\prime}}+1\right)}=\frac{T_{c t}+1}{\left(\sum_{t^{\prime} \in V^{\prime}} T_{c t^{\prime}}\right)+B^{\prime}}
$$

dimana:

$$
B \quad \text { : Jumlah seluruh term pada vocabulary }
$$

Sedangkan untuk rumus multinomial naïve Bayes dengan menggunakan pembobotan TF-IDF dapat dilihat pada persamaan (7) [11].

$$
\hat{P}(t \mid c)=\frac{W_{c t}+1}{\left(\sum_{w \prime \in V} W_{c t \prime}\right)+B^{\prime}}
$$

dimana :

$W_{c t} \quad$ : Bobot TF-IDF term $t$ pada dokumen dengan kategori $c$ $\sum_{w^{\prime} \in V} W_{c t}$ : Jumlah bobot TF-IDF seluruh term pada kelas $c$

$B^{\prime} \quad$ : Jumlah IDF seluruh term pada vocabulary

\subsection{K-fold Cross Validation}

$K$-fold cross validation merupakan salah satu teknik validasi silang dengan cara membagi data menjadi $k$ bagian dengan ukuran yang sama. Pelatihan dan pengujian dilakukan sebanyak $k$ kali. Pada percobaan pertama, subset S1 diberlakukan sebagai data pengujian, dan subset lainnya digunakan sebagai data training. Pada percobaan ke-2, subset S2 diberlakukan sebagai data pengujian, kemudian subset lainnya digunakan sebagai data training. Proses ini dilakukan sampai $k$ kali dimana subset $S k$ dijadikan data pengujian [12].

\section{Metode Penelitian}

Pada penelitian ini terdapat 6 kategori klasifikasi artikel yang digunakan yaitu kategori Ekonomi Gempa, Kesehatan Gempa, Pariwisata Gempa, Ekonomi Nongempa, Kesehatan Non-gempa, dan Pariwisata Nongempa. Pengumpulan data diarahkan oleh pakar IImu Komunikasi dengan kualifikasi Master. Artikel Kesehatan Gempa dan Kesehatan Non-gempa dikumpulkan dari kanal health.detik.com serta www.liputan6.com/health. Artikel Ekonomi Gempa dan Ekonomi Non-gempa dikumpulkan dari kanal finance.detik.com, economy.okezone.com, serta ekonomi.kompas.com. Sedangkan untuk artikel Pariwisata Gempa dan Pariwisata Non-gempa, dikumpulkan dari kanal travel.detik.com serta travel.kompas.com. Artikel yang dikumpulkan adalah sejumlah 1000 artikel. Dari 1000 artikel yang terkumpul, terdapat 100 artikel untuk label Kesehatan Gempa, 100 artikel untuk label Ekonomi Gempa, 100 artikel untuk label Pariwisata Gempa, 230 artikel untuk label Kesehatan Non-gempa, 230 artikel untuk label Ekonomi Non-gempa, 240 artikel untuk label Pariwisata Non-gempa.

Rancangan dari sistem klasifikasi artikel online gempa di Indonesia menggunakan multinomial naïve Bayes text classification terdiri dari beberapa tahapan, yang dapat dilihat pada Gambar 1. 


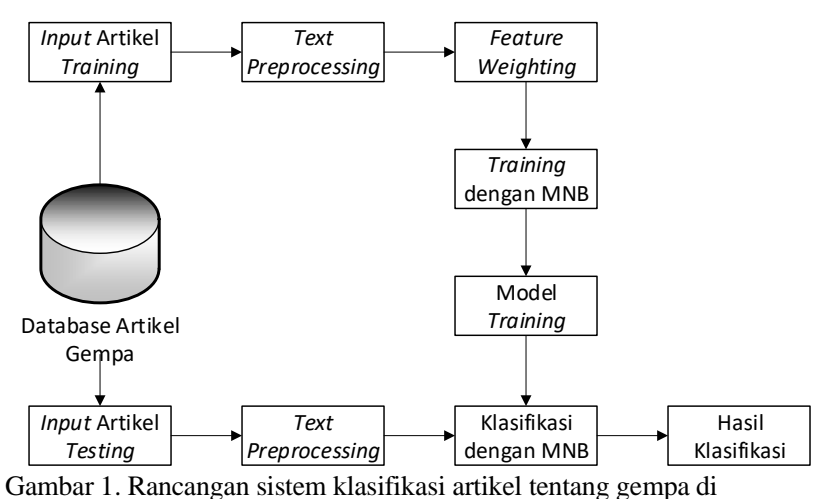

Rancangan sistem klasifikasi artikel tentang gempa di indonesia.

\subsection{Input Artikel Training dan Testing}

Pada tahap ini, artikel yang telah dikumpulkan dibagi menjadi 2 yaitu artikel training dan artikel testing. Artikel training digunakan untuk membuat model klasifikasi sedangkan artikel testing digunakan untuk menguji model yang telah dibuat.

\subsubsection{Artikel training}

Artikel training yang sebelumnya telah diberi label kategori dimasukan ke dalam sistem untuk diproses. Artikel yang didapatkan dari subdomain health.detik.com, dan www.liputan6.com/health diberi kategori Kesahatan Gempa dan Kesehatan Non-gempa. Artikel yang didapatkan dari subdomain finance.detik.com, economy.okezone.com, dan ekonomi.kompas.com diberi kategori Ekonomi Gempa dan Ekonomi Non-gempa. Sedangkan untuk artikel yang didapatkan dari subdomain travel.detik.com dan travel.kompas.com diberi kategori Pariwisata dan Pariwisata Non-gempa. Setelah artikel diberi label, dilakukan preprocessing dan pembobotan pada artikel, yang kemudian di-training menggunakan naïve Bayes classifier.

\subsubsection{Artikel testing}

Artikel testing merupakan artikel yang diambil dari dataset tetapi tidak diberi label seperti artikel training. Artikel testing dimasukan ke sistem untuk diprediksikan kategorinya. Sebelum diklasifikasikan, artikel testing juga terlebih dahulu melewati tahap preprocessing.

\subsection{Text Preprocessing}

Text preprocessing yang dilakukan pada penelitian ini dibagi menjadi 3 tahap, yaitu tahap tokenization, stemming, dan stop-word removal.

\subsubsection{Tokenization}

Tokenization merupakan untuk mentransformasikan artikel menjadi kumpulan kata yang disebut terms. Pada tokenization juga dilakukan penghilangan tanda baca. Hal ini dilakukan karena tanda baca tidak dapat digunakan sebagai terms karena terdapat pada hampir seluruh dokumen. Sebelum proses tokenization, terlebih dahulu dilakukan proses case folding atau mengubah setiap kata menjadi huruf kecil. Tujuannya adalah agar tidak terjadi kesalahan interpretasi oleh komputer ketika ada dua kata yang sama tapi dianggap berbeda karena perbedaan huruf besar dan huruf kecil.

\subsubsection{Stemming}

Proses stemming dilakukan dengan menggunakan algoritma Nazief dan Adriani karena artikel yang digunakan pada penelitian merupakan artikel berbahasa Indonesia. Selain itu, algoritma Nazief dan Adriani terbukti dapat memberikan akurasi yang lebih akurat dibandingkan dengan algoritma lainnya seperti Arifin dan Setiono, Vega, serta Tala [13]. Algoritma Nazief dan Adriani melakukan stemming dengan menghilangkan inflection suffixes ("-lah", "-kah", "-ku”, "-mu", atau "-nya"), possesive pronouns ("-ku", "-mu", atau "-nya"), derivation suffixes ("-i", "-an" atau "-kan") dan derivation prefixes ("di-","ke-","se-","te-", "be-", "me-", atau "pe-"), kemudian mencocokan kata dengan kata yang ada di kamus [14].

\subsubsection{Stop-word removal}

Stop-word removal merupakan proses menghilangkan stop words yang tidak dapat mewakili isi artikel. Proses ini dilakukan untuk meningkatkan efisiensi dalam proses training maupun klasifikasi. Stop words yang dihillangkan didasarkan dari stop words pada library Sastrawi.

\subsection{Feature Weighting}

Feature weighting merupakan suatu proses untuk menghitung serta memberi bobot pada suatu feature sebagai derajat kepentingannya. Term frequency dan pembobotan TF-IDF merupakan metode yang sering digunakan dalam pembobotan kata[3].

Metode TF-IDF (Term Frequency - Inverse Document Frequency) merupakan suatu metode yang menggabungkan 2 cara untuk memberikan bobot pada kata, yaitu dengan menghitung term frequency dan melakukan perhitungan invers dari jumlah dokumen yang mengandung kata tersebut (IDF) [6]. Karena dilakukan pula perhitungan IDF, maka metode TF-IDF membutuhkan referensi dari seluruh dokumen (corpus) [3]. Perhitungan TF dan IDF dapat dilakukan dengan Persamaan (8) dan (9) [4]. 


$$
\begin{aligned}
& T F(d, t)=f(d, t) \\
& I D F(t)=\log \left(\frac{N_{d}}{d f(t)}\right)
\end{aligned}
$$

dimana :

$T F(d, t)$ : Term frequency

$f(d, t)$ : Frekuensi term t pada dokumen d

$I D F(t)$ : Inverse document frequency

$N_{d} \quad$ : Jumlah dokumen keseluruhan

$d f(t) \quad$ : Jumlah dokumen yang mengandung term $\mathrm{t}$

Sehingga untuk perhitungan TF-IDF dari suatu kata pada dokumen dapat dilakukan dengan Persamaan.

$$
T F-I D F=T F(d, t) . I D F(t)
$$

\subsection{Training}

Pada penelitian ini, training dan klasifikasi dilakukan menggunakan metode Naïve Bayes dengan model multinomial. Proses training diawali dengan menghitung probabilitas prior dari setiap kategori menggunakan Persamaan (4). Setelah didapatkan probabilitas prior dari tiap kategori, proses training dilanjutkan dengan menghitung probabilitas suatu feature terdapat pada suatu kategori. Proses perhitungan dilakukan dengan Persamaan (7).

Pada tahap klasifikasi, ada kemungkinan terdapat suatu feature pada artikel testing yang tidak pernah muncul di artikel training. Apabila ditemukan kasus seperti ini, maka $P(t \mid c)$ dari feature tersebut adalah nilai $P(t \mid c)$ paling kecil dari tiap kategori.

\subsection{Klasifikasi}

Tujuan dari proses klasifikasi adalah untuk mengetahui kategori dari suatu artikel. Proses ini memanfaatkan model Naïve Bayes yang telah didapatkan saat training untuk melakukan perhitungan probabilistik pada artikel yang ingin diklasifikasikan. Penentuan kategori suatu artikel dilakukan menggunakan Persamaan (3). Pada Persamaan (3), dilakukan perbandingan terhadap probabilitas suatu artikel berada di suatu kategori $c$ untuk tiap kategori. Sebelum dilakukan klasifikasi, artikel testing terlebih dahulu melewati proses preprocessing.

\subsection{Evaluasi}

Pengujian yang dilakukan dalam penelitian tentang klasifikasi artikel online gempa di Indonesia menggunakan multinomial naïve Bayes text classification adalah dengan teknik $k$-fold cross validation. Nilai $k$ yang digunakan adalah 5 karena jumlah dataset yang cukup terbatas, dimana dataset untuk artikel gempa sendiri hanya terdapat 100 artikel untuk tiap kategori.

Teknik yang digunakan untuk melakukan evaluasi dalam klasifikasi pada penelitian ini adalah dengan menghitung recall, precision, dan $f$-measure. Teknik ini menggunakan confusion matrix sebagai acuan perhitungan [11].

Recall untuk kelas $c$ merupakan perbandingan dari jumlah dokumen yang diklasifikasikan benar pada kelas $c$ dengan jumlah seluruh dokumen yang sebenarnya berada pada kelas $c$. Perhitungan recall pada suatu kelas $c$ dapat dilakukan dengan Persamaan (11) [11].

$$
\operatorname{Recall}_{c}=\frac{T P(\text { Kelas }-c)}{\text { Total }(\text { Kelas }-c)}
$$

Precision untuk kelas $c$ merupakan perbandingan dari jumlah dokumen yang diklasifikasikan benar pada kelas $c$ dengan jumlah dokumen yang diklasifikasikan sebagai kelas $c$. Precision pada suatu kelas $c$ dapat dihitung dengan menggunaan Persamaan (12) [11].

$$
\text { Precision }_{c}=\frac{T P(\text { Kelas }-c)}{\text { Prediksi }(\text { Kelas }-c)}
$$

Sedangkan $f$-measure merupakan nilai yang mewakili seluruh kinerja sistem yang merupakan penggabungan nilai recall dan rrecision. F-measure dapat dihitung menggunakan Persamaan (13) [2].

$$
F-\text { measure }_{c}=\frac{2 P R}{P+R}
$$

Pada setiap percobaan, evaluasi dilakukan dengan menghitung recall, precision, dan $f$-measure dari model. Nilai recall, precision, dan $f$-measure untuk tiap percobaan didapatkan dengan mencari nilai rata-rata dari recall, precision, dan $f$-measure per kategori. Performa model secara keseluruhan didapatkan dengan menghitung nilai rata-rata recall, precision, dan $f$-measure dari seluruh percobaan.

Terdapat beberapa skema pengujian yang dilakukan pada penelitian ini, antara lain adalah klasifikasi hanya dengan menggunakan feature unigram, klasifikasi hanya dengan menggunakan feature bigram, dan klasifikasi dengan feature unigram dan bigram. Selain itu, dilakukan juga pengujian dengan stemming, tanpa stemming, dengan stopwords removal, dan tanpa stopwords removal.

\section{4. hasil dan pembahasan}

Berdasarkan beberapa skema pengujian yang dilakukan dengan 5 perulangan 5-fold cross validation, didapatkan nilai precision dan recall yang kemudian diwakilkan oleh nilai $f$-measure. Selain itu, didapatkan juga panjang vocabulary dari masing-masing pengujian. 
Grafik perbandingan panjang vocabulary dan perbandingan nilai $f$-measure untuk tiap pengujian dapat dilihat pada Gambar 2 dan Gambar 3.

घunigram $\square$ Bigram $\square$ Unigram + Bigram

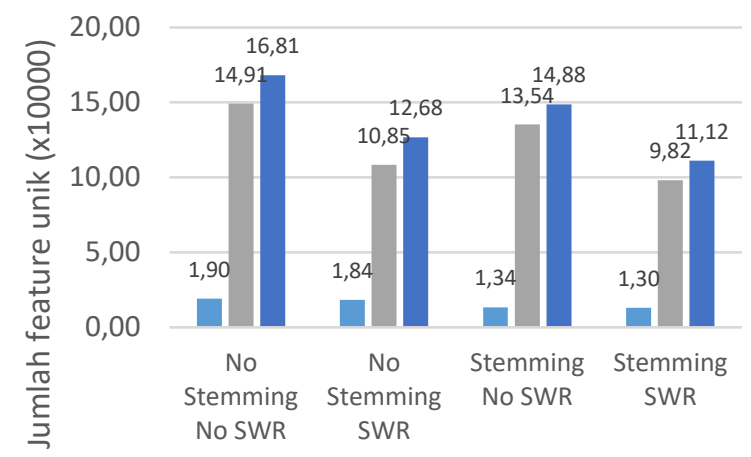

Gambar 2. Pengaruh jenis pengujian terhadap ukuran vocabulary.

च Unigram $\quad$ Bigram $\quad$ Unigram + Bigram

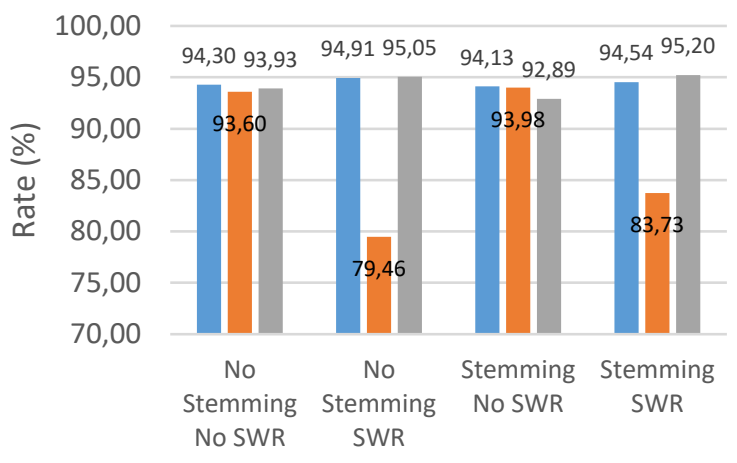

Gambar 3. Pengaruh jenis pengujian terhadap nilai $f$-measure.

Pada Gambar 2, ukuran vocabulary yang didapatkan dari tiap jenis feature berbeda-beda satu sama lain. Feature unigram memiliki ukuran vocabulary jauh lebih kecil dibandingkan dengan feature bigram. Hal ini disebabkan oleh pasangan kata yang bervariasi dalam tiap dokumen. Ukuran vocabulary dari penggunaan feature unigram bersamaan dengan feature bigram sendiri merupakan jumlah dari ukuran 2 jenis feature tersebut. Selain itu, dapat dilihat juga penggunaan stemming dan stopwords removal juga dapat mengurangi ukuran dari vocabulary.

Pada Gambar 3, dapat dilihat bahwa penggunaan stemming mengurangi nilai $f$-measure dari pengujian menggunakan feature unigram. Hal ini juga berlaku pada pengujian yang menggunakan feature unigram sekaligus bigram dan menyertakan stopwords. Akan tetapi, nilai $f$-measure yang didapatkan pada pengujian dengan menggunakan stemming justru mengalami peningkatan pada feature bigram Nilai f-measure dari feature unigram sekaligus bigram yang tidak menyertakan stopwords juga mengalami peningkatan ketika dilakukan stemming.

Pada Gambar 3 juga dapat dilihat bahwa penghilangan stopwords dapat meningkatkan nilai $f$ measure untuk pengujian dengan feature unigram dan juga feature unigram sekaligus bigram. Akan tetapi, stopwords removal pada pengujian dengan feature bigram justru dapat mengurangi nilai $f$-measure secara signifikan.

\subsection{Pengujian tanpa Stemming dan Stopwords Removal}

Pada skema pengujian ini, tidak dilakukan stemming maupun stopwords removal pada data training. Hasil training menggunakan seluruh dataset menghasilkan vocabulary dengan panjang 19016 untuk feature unigram dan 149125 untuk feature bigram. 5 feature dengan bobot tertinggi untuk masing-masing jenis feature dan kategori dapat dilihat pada Tabel I, Tabel II, Tabel III, dan Tabel IV.

TABLE I. FEATURE UNIGRAM TANPA STEMMING DAN STOPWORDS REMOVAL PADA ARTIKEL GEMPA

\begin{tabular}{|c|c|c|c|c|c|}
\hline \multicolumn{2}{|c|}{ Ekonomi Gempa } & \multicolumn{2}{c|}{ Kesehatan Gempa } & \multicolumn{2}{c|}{ Pariwisata Gempa } \\
\hline Feature & Bobot & Feature & Bobot & Feature & Bobot \\
\hline palu & 201.123 & kesehatan & 241.043 & gili & 290.8 \\
\hline rp & 191.195 & korban & 232.627 & lombok & 264.151 \\
\hline bank & 190.703 & gempa & 168.47 & gempa & 220.717 \\
\hline bantuan & 181.44 & lombok & 150.315 & pariwisata & 207.101 \\
\hline lombok & 176.101 & palu & 149.352 & wisatawan & 203.849 \\
\hline
\end{tabular}

TABLE II. FEATURE UNIGRAM TANPA STEMMING DAN STOPWORDS REMOVAL PADA ARTIKEL NON-GEMPA.

\begin{tabular}{|c|c|c|c|c|c|}
\hline \multicolumn{2}{|c|}{$\begin{array}{c}\text { Ekonomi Non- } \\
\text { gempa }\end{array}$} & \multicolumn{2}{c|}{$\begin{array}{c}\text { Kesehatan Non- } \\
\text { gempa }\end{array}$} & \multicolumn{2}{c|}{$\begin{array}{c}\text { Pariwisata Non- } \\
\text { gempa }\end{array}$} \\
\hline Feature & Bobot & Feature & Bobot & Feature & Bobot \\
\hline saham & 304.75 & jantung & 369.96 & pantai & 243.68 \\
\hline rp & 291.20 & anda & 343.13 & gili & 227.26 \\
\hline harga & 265.44 & kanker & 266.28 & wisata & 223.99 \\
\hline banjir & 233.93 & serangan & 254.43 & pengunjung & 218.87 \\
\hline tol & 227.72 & seks & 245.70 & gunung & 214.86 \\
\hline
\end{tabular}

TABLE III. FEATURE BIGRAM TANPA STEMMING DAN STOPWORDS REMOVAL PADA ARTIKEL GEMPA.

\begin{tabular}{|c|c|c|c|c|c|}
\hline \multicolumn{2}{|c|}{ Ekonomi Gempa } & \multicolumn{2}{c|}{ Kesehatan Gempa } & \multicolumn{2}{c|}{ Pariwisata Gempa } \\
\hline Feature & Bobot & Feature & Bobot & Feature & Bobot \\
\hline rp miliar & 157.2 & $\begin{array}{c}\text { korban } \\
\text { gempa }\end{array}$ & 122.9 & $\begin{array}{c}\text { gili } \\
\text { trawangan }\end{array}$ & 116.1 \\
\hline $\begin{array}{c}\text { rp } \\
\text { triliun }\end{array}$ & 88.87 & rumah sakit & 99.16 & $\begin{array}{c}\text { gunung } \\
\text { rinjani }\end{array}$ & 92.9 \\
\hline $\begin{array}{c}\text { sri } \\
\text { mulyani }\end{array}$ & 88.33 & $\begin{array}{c}\text { lombok } \\
\text { utara }\end{array}$ & 85.1 & gili air & 90.98 \\
\hline $\begin{array}{c}\text { di palu } \\
\text { di }\end{array}$ & 86.87 & $\begin{array}{c}\text { kementerian } \\
\text { lombehatan }\end{array}$ & 82.44 & di & 83.45 \\
\hline lombok & 82.63 & rsud tanjung & 76.60 & di gili & 76.52 \\
\hline
\end{tabular}


TABLE IV. FEATURE BIGRAM TANPA STEMMING DAN STOPWORDS REMOVAL PADA ARTIKEL NON-GEMPA.

\begin{tabular}{|c|c|c|c|c|c|}
\hline \multicolumn{2}{|c|}{$\begin{array}{c}\text { Ekonomi Non- } \\
\text { gempa }\end{array}$} & \multicolumn{2}{c|}{$\begin{array}{c}\text { Kesehatan Non- } \\
\text { gempa }\end{array}$} & \multicolumn{2}{c|}{$\begin{array}{c}\text { Pariwisata Non- } \\
\text { gempa }\end{array}$} \\
\hline Feature & Bobot & Feature & Bobot & Feature & Bobot \\
\hline jalan tol & 170.61 & $\begin{array}{c}\text { serangan } \\
\text { jantung }\end{array}$ & 221.91 & $\begin{array}{c}\text { kompas } \\
\text { com }\end{array}$ & 108.7 \\
\hline $\begin{array}{c}\text { rp } \\
\text { triliun }\end{array}$ & 146.24 & $\begin{array}{c}\text { dikutip } \\
\text { dari }\end{array}$ & 90.658 & $\begin{array}{c}\text { gili } \\
\text { trawangan }\end{array}$ & 106.8 \\
\hline $\begin{array}{c}\text { menjadi } \\
\text { rp }\end{array}$ & 115.77 & $\begin{array}{c}\text { bunuh } \\
\text { diri }\end{array}$ & 88.874 & $\begin{array}{c}\text { gunung } \\
\text { rinjani }\end{array}$ & 105.1 \\
\hline $\begin{array}{c}\text { harga } \\
\text { rokok }\end{array}$ & 109.39 & $\begin{array}{c}\text { nyeri } \\
\text { dada }\end{array}$ & 88 & gili air & 90.98 \\
\hline rp ribu & 92.947 & $\begin{array}{c}\text { getah } \\
\text { bening }\end{array}$ & 81.83 & di bali & 76.52 \\
\hline
\end{tabular}

Pada tabel yang disajikan, dapat dilihat beberapa feature yang sama pada kategori ekonomi, kesehatan, dan pariwisata untuk artikel tentang gempa maupun artikel non-gempa. Hal ini disebabkan karena artikel dengan kategori yang sama, baik artikel tersebut merupakan artikel gempa maupun artikel non-gempa, memiliki beberapa feature kunci yang sama. Akan tetapi, feature-feature tersebut tidak terlalu berpengaruh dalam menentukan apakah suatu artikel termasuk ke dalam artikel gempa atau non gempa, karena terdapat beberapa feature yang hanya terdapat pada artikel gempa. Feature-feature tersebut memiliki peran yang penting dalam mengelompokan suatu artikel ke dalam kategori gempa. Selain dari feature yang hanya ada untuk artikel gempa tersebut, feature lain di dalam vocabulary sangat beragam untuk masingmasing kategori, sehingga menghasilkan akurasi yang tinggi saat dilakukan klasifikasi artikel.

Hasil yang didapatkan dari skema pengujian ini melalui 5-fold cross validation dapat dilihat pada Tabel v.

TABLE V. HASIL PENGUJIAN TANPA StEMming DAN STOPWORDS REMOVAL

\begin{tabular}{|c|c|c|c|c|}
\hline Jenis Feature & Precision & Recall & $\begin{array}{c}\text { F- } \\
\text { Measure }\end{array}$ & $\begin{array}{c}\text { Standar } \\
\text { Deviasi }\end{array}$ \\
\hline Unigram & $95.21 \%$ & $93.66 \%$ & $94.30 \%$ & $1.09 \%$ \\
\hline Bigram & $93.12 \%$ & $94.46 \%$ & $93.60 \%$ & $1.69 \%$ \\
\hline Unigram dan Bigram & $95.21 \%$ & $93.04 \%$ & $93.93 \%$ & $1.43 \%$ \\
\hline
\end{tabular}

\subsection{Pengujian tanpa Stemming dengan Stopwords Removal}

Pada skema pengujian ini, tidak dilakukan stemming, akan tetapi dilakukan stopwords removal pada data training. Hasil training menggunakan seluruh dataset menghasilkan vocabulary dengan panjang 18374 untuk feature unigram dan 108474 untuk feature bigram. 5 feature dengan bobot tertinggi untuk masing-masing jenis feature dan kategori dapat dilihat pada Tabel VI, Tabel VII, Tabel VIII, dan Tabel IX.

\section{TABLE VI. FEATURE UNIGRAM TANPA STEMMING DAN STOPWORDS PADA ARTIKEL GEMPA.}

\begin{tabular}{|c|r|c|r|c|c|}
\hline \multicolumn{2}{|c|}{ Ekonomi Gempa } & \multicolumn{2}{c|}{ Kesehatan Gempa } & \multicolumn{2}{c|}{ Pariwisata Gempa } \\
\hline Feature & Bobot & Feature & Bobot & Feature & Bobot \\
\hline palu & 201.13 & kesehatan & 241 & gili & 290.8 \\
\hline rp & 191.2 & korban & 232.6 & lombok & 264.2 \\
\hline bank & 190.7 & gempa & 168.5 & gempa & 220.7 \\
\hline bantuan & 181.44 & lombok & 150.3 & pariwisata & 207.1 \\
\hline lombok & 176.1 & palu & 149.4 & wisatawan & 203.8 \\
\hline
\end{tabular}

TABLE VII. FEATURE UNIGRAM TANPA STEMMING DAN STOPWORDS PADA ARTIKEL NON-GEMPA.

\begin{tabular}{|c|r|c|r|c|r|}
\hline \multicolumn{2}{|c|}{$\begin{array}{c}\text { Ekonomi Non- } \\
\text { gempa }\end{array}$} & \multicolumn{2}{c|}{$\begin{array}{c}\text { Kesehatan Non- } \\
\text { gempa }\end{array}$} & \multicolumn{2}{c|}{$\begin{array}{c}\text { Pariwisata Non- } \\
\text { gempa }\end{array}$} \\
\hline Feature & Bobot & Feature & Bobot & Feature & Bobot \\
\hline saham & 304.75 & jantung & 369.96 & pantai & 243.7 \\
\hline rp & 291.2 & kanker & 266.28 & gili & 227.3 \\
\hline harga & 265.44 & serangan & 254.43 & wisata & 224 \\
\hline banjir & 233.93 & seks & 245.7 & pengunjung & 218.9 \\
\hline tol & 227.72 & pneumonia & 236.05 & gunung & 214.9 \\
\hline
\end{tabular}

TABLE VIII. FEATURE BIGRAM TANPA STEMMING DAN STOPWORDS PADA ARTIKEL GEMPA.

\begin{tabular}{|c|c|c|c|c|c|}
\hline \multicolumn{2}{|c|}{ Ekonomi Gempa } & \multicolumn{2}{c|}{ Kesehatan Gempa } & \multicolumn{2}{c|}{ Pariwisata Gempa } \\
\hline Feature & Bobot & Feature & Bobot & Feature & Bobot \\
\hline $\begin{array}{c}\mathrm{rp} \\
\text { miliar }\end{array}$ & 157.18 & $\begin{array}{c}\text { korban } \\
\text { gempa }\end{array}$ & 123.85 & $\begin{array}{c}\text { gili } \\
\text { trawangan }\end{array}$ & 116.1 \\
\hline $\begin{array}{c}\mathrm{rp} \\
\text { triliun }\end{array}$ & 88.87 & rumah sakit & 99.161 & $\begin{array}{c}\text { gunung } \\
\text { rinjani }\end{array}$ & 92.9 \\
\hline $\begin{array}{c}\text { sri } \\
\text { mulyani }\end{array}$ & 88.327 & $\begin{array}{c}\text { lombok } \\
\text { utara }\end{array}$ & 84.706 & gili air & 90.98 \\
\hline $\begin{array}{c}\text { rp juta } \\
\text { kantor } \\
\text { cabang }\end{array}$ & 79.624 & $\begin{array}{c}\text { kementerian } \\
\text { kesehatan }\end{array}$ & 82.442 & $\begin{array}{c}\text { jalur } \\
\text { pendakian }\end{array}$ & 65.41 \\
\hline tanjung & 76.604 & $\begin{array}{c}\text { gempa } \\
\text { bumi }\end{array}$ & 64.21 \\
\hline
\end{tabular}

TABLE IX. FeAtURE BIGRAM TANPA StEMming DAN STOPWORDS PADA ARTIKEL NON-GEMPA.

\begin{tabular}{|c|c|c|c|c|c|}
\hline \multicolumn{2}{|c|}{$\begin{array}{c}\text { Ekonomi Non- } \\
\text { gempa }\end{array}$} & \multicolumn{2}{c|}{$\begin{array}{c}\text { Kesehatan Non- } \\
\text { gempa }\end{array}$} & \multicolumn{2}{c|}{$\begin{array}{c}\text { Pariwisata Non- } \\
\text { gempa }\end{array}$} \\
\hline Feature & Bobot & Feature & Bobot & Feature & Bobot \\
\hline $\begin{array}{c}\text { jalan } \\
\text { tol }\end{array}$ & 170.61 & $\begin{array}{c}\text { serangan } \\
\text { jantung }\end{array}$ & 221.91 & $\begin{array}{c}\text { kompas } \\
\text { com }\end{array}$ & 108.7 \\
\hline $\begin{array}{c}\text { rp } \\
\text { triliun }\end{array}$ & 146.24 & $\begin{array}{c}\text { nyeri } \\
\text { dada }\end{array}$ & 90 & $\begin{array}{c}\text { gili } \\
\text { trawangan }\end{array}$ & 108.1 \\
\hline $\begin{array}{c}\text { harga } \\
\text { rokok }\end{array}$ & 111.28 & $\begin{array}{c}\text { getah } \\
\text { bening }\end{array}$ & 81.83 & $\begin{array}{c}\text { gunung } \\
\text { rinjani }\end{array}$ & 105.1 \\
\hline $\begin{array}{c}\text { rp ribu } \\
\text { getah }\end{array}$ & 92.947 & $\begin{array}{c}\text { kelenjar } \\
\text { getah }\end{array}$ & 79.683 & gili air & 90.98 \\
\hline $\begin{array}{c}\text { dollar } \\
\text { as }\end{array}$ & 82.62 & $\begin{array}{c}\text { paru } \\
\text { paru }\end{array}$ & 71.132 & $\begin{array}{c}\text { kembang } \\
\text { api }\end{array}$ & 75.69 \\
\hline
\end{tabular}

Pada tabel yang disajikan, terdapat beberapa feature yang dihilangkan baik untuk feature unigram maupun feature bigram dibandingkan dengan pengujian tanpa menghilangkan stop words. Untuk 
feature unigram, pengaruh dari penghilangan stop words tidak terlalu tinggi terhadap proses klasifikasi. Hal ini dikarenakan pemberian bobot feature dilakukan dengan TF-IDF yang mana mempertimbangkan kemunculan feature diseluruh dokumen pada corpus. Stop words merupakan kata yang umum dan muncul di hampir seluruh dokumen, sehingga IDF-nya lebih rendah dibandingkan dengan feature lainnya, dan menyebabkan bobot-nya tidak terlalu tinggi.

Akan tetapi, penghilangan stop words pada feature bigram memiliki pengaruh yang cukup signifikan. Hal ini terjadi karena penghilangan stop words akan menyebabkan 2 terms yang dipisahkan oleh stop words dianggap bersebelahan. Konsep dasar dari bigram yang menyatukan 2 terms yang bersebalahan akan diabaikan. Imbasnya, feature yang terdapat pada vocabulary menjadi tidak representatif terhadap dokumen. Contoh feature penting dengan bobot tinggi yang dihilangkan pada proses stop words removal adalah "gempa di" dan "para korban" untuk artikel gempa serta "menjadi rp" dan "di bali" untuk artikel non-gempa.

Hasil yang didapatkan dari skema pengujian ini melalui 5-fold cross validation dapat dilihat pada Tabel $\mathrm{X}$.

TABLE X. HASIL PENGUJIAN TANPA STEMMING DAN STOPWORDS.

\begin{tabular}{|c|c|c|c|c|}
\hline Jenis Feature & Precision & Recall & $\begin{array}{c}\text { F- } \\
\text { Measure }\end{array}$ & $\begin{array}{c}\text { Standar } \\
\text { Deviasi }\end{array}$ \\
\hline Unigram & $94.58 \%$ & $95.51 \%$ & $94.91 \%$ & $1.54 \%$ \\
\hline Bigram & $79.93 \%$ & $84.96 \%$ & $79.46 \%$ & $2.99 \%$ \\
\hline Unigram dan Bigram & $94.84 \%$ & $95.46 \%$ & $95.05 \%$ & $1.65 \%$ \\
\hline
\end{tabular}

\subsection{Pengujian dengan Stemming tanpa Stopwords Removal}

Pada skema pengujian ini, dilakukan stemming tanpa stopwords removal pada data training. Hasil training menggunakan seluruh dataset menghasilkan vocabulary dengan panjang 13354 untuk feature unigram dan 135399 untuk feature bigram. 5 feature dengan bobot tertinggi untuk masing-masing jenis feature dan kategori dapat dilihat pada Tabel XI, Tabel XII, Tabel XIII, dan Tabel XIV.

TABLE XI. FEATURE UNIGRAM DENGAN STEMMING DAN STOPWORDS PADA ARTIKEL GEMPA.

\begin{tabular}{|c|r|c|c|c|c|}
\hline \multicolumn{2}{|c|}{ Ekonomi Gempa } & \multicolumn{2}{c|}{ Kesehatan Gempa } & \multicolumn{2}{c|}{ Pariwisata Gempa } \\
\hline Feature & Bobot & Feature & Bobot & Feature & Bobot \\
\hline palu & 201.13 & korban & 231.91 & gili & 290.8 \\
\hline rp & 191.2 & sehat & 227.37 & lombok & 264.2 \\
\hline bank & 190.7 & gempa & 168.47 & gempa & 221.8 \\
\hline lombok & 176.1 & lombok & 150.31 & pariwisata & 211.2 \\
\hline bencana & 175.91 & palu & 149.35 & wisatawan & 203.8 \\
\hline
\end{tabular}

TABLE XII. FEATURE UNIGRAM DENGAN STEMMING DAN STOPWORDS PADA ARTIKEL NON-GEMPA.

\begin{tabular}{|c|r|c|r|c|c|}
\hline \multicolumn{2}{|c|}{$\begin{array}{c}\text { Ekonomi Non- } \\
\text { gempa }\end{array}$} & \multicolumn{2}{c|}{$\begin{array}{c}\text { Kesehatan Non- } \\
\text { gempa }\end{array}$} & \multicolumn{2}{c|}{$\begin{array}{c}\text { Pariwisata Non- } \\
\text { gempa }\end{array}$} \\
\hline Feature & Bobot & Feature & Bobot & Feature & Bobot \\
\hline saham & 310.34 & jantung & 373.9 & pantai & 248.1 \\
\hline rp & 291.2 & anda & 339 & wisata & 227.5 \\
\hline harga & 256.82 & sakit & 298.4 & gili & 227.3 \\
\hline banjir & 233.91 & kanker & 271 & gunung & 220.5 \\
\hline tol & 225.15 & serang & 249.5 & unjung & 216.6 \\
\hline
\end{tabular}

TABLE XIII. FEATURE BIGRAM DENGAN STEMMING DAN STOPWORDS PADA ARTIKEL GEMPA.

\begin{tabular}{|c|c|c|c|c|c|}
\hline \multicolumn{2}{|c|}{ Ekonomi Gempa } & \multicolumn{2}{c|}{ Kesehatan Gempa } & \multicolumn{2}{c|}{ Pariwisata Gempa } \\
\hline Feature & Bobot & Feature & Bobot & Feature & Bobot \\
\hline rp miliar & 157.18 & $\begin{array}{c}\text { korban } \\
\text { gempa }\end{array}$ & 122.87 & $\begin{array}{c}\text { gili } \\
\text { trawangan }\end{array}$ & 116.1 \\
\hline rp triliun & 88.87 & $\begin{array}{c}\text { rumah } \\
\text { sakit }\end{array}$ & 100.18 & $\begin{array}{c}\text { gunung } \\
\text { rinjani }\end{array}$ & 92.9 \\
\hline $\begin{array}{c}\text { sri } \\
\text { mulyani }\end{array}$ & 88.327 & $\begin{array}{c}\text { menteri } \\
\text { sehat }\end{array}$ & 86.387 & gili air & 90.98 \\
\hline di palu & 86.87 & $\begin{array}{c}\text { lombok } \\
\text { utara }\end{array}$ & 85.099 & di lombok & 83.45 \\
\hline di lombok & 82.634 & $\begin{array}{c}\text { rsud } \\
\text { tanjung }\end{array}$ & 76.604 & di gili & 76.52 \\
\hline
\end{tabular}

TABLE XIV. FEATURE BIGRAM DENGAN STEMMING DAN STOPWORDS PADA ARTIKEL NON-GEMPA.

\begin{tabular}{|c|c|c|c|c|c|}
\hline \multicolumn{2}{|c|}{$\begin{array}{c}\text { Ekonomi Non- } \\
\text { gempa }\end{array}$} & \multicolumn{2}{c|}{$\begin{array}{c}\text { Kesehatan Non- } \\
\text { gempa }\end{array}$} & \multicolumn{2}{c|}{$\begin{array}{c}\text { Pariwisata Non- } \\
\text { gempa }\end{array}$} \\
\hline Feature & Bobot & Feature & Bobot & Feature & Bobot \\
\hline $\begin{array}{c}\text { jalan } \\
\text { tol }\end{array}$ & 170.61 & $\begin{array}{c}\text { serang } \\
\text { jantung }\end{array}$ & 221.91 & $\begin{array}{c}\text { kompas } \\
\text { com }\end{array}$ & 108.7 \\
\hline $\begin{array}{c}\text { rp } \\
\text { triliun }\end{array}$ & 146.24 & $\begin{array}{c}\text { orang } \\
\text { yang }\end{array}$ & 101.25 & $\begin{array}{c}\text { gili } \\
\text { trawangan }\end{array}$ & 106.8 \\
\hline jadi rp & 118.24 & $\begin{array}{c}\text { kutip } \\
\text { dari }\end{array}$ & 90.378 & $\begin{array}{c}\text { gunung } \\
\text { rinjani }\end{array}$ & 105.1 \\
\hline $\begin{array}{c}\text { harga } \\
\text { rokok }\end{array}$ & 109.39 & $\begin{array}{c}\text { bunuh } \\
\text { diri }\end{array}$ & 88.874 & gili air & 90.98 \\
\hline rp ribu & 92.328 & $\begin{array}{c}\text { nyeri } \\
\text { dada }\end{array}$ & 88 & ada di & 88.11 \\
\hline
\end{tabular}

Pada tabel yang disajikan, terdapat beberapa feature yang berbeda dibandingkan dengan pengujian tanpa melakukan stemming. Proses stemming untuk feature unigram dapat mengurangi akurasi dari model walaupun tidak terlalu signifikan. Hal ini dapat dilihat dari terms yang penting untuk suatu kategori yang telah diubah menjadi kata dasarnya memiliki bobot yang lebih rendah dibandingkan dengan sebelum dilakukan stemming. Contoh term penting yang mengalami penurunan bobot akibat stemming dapat dilihat pada Tabel XV. 
TABLE XV. FEATURE UNIGRAM PENTING YANG MENGALAMI PERUBAHAN BOBOT SETELAH STEMMING.

\begin{tabular}{|c|c|c|}
\hline \multicolumn{2}{|c|}{ Term } & \multirow{2}{*}{ Kategori } \\
\cline { 1 - 2 } Sebelum stemming & Setelah stemming & \multirow{2}{*}{ Ekonomi Gempa } \\
bantuan (TF = 259, IDF & bantu (TF = 204, & \\
IDF $=0.8894)$ & Pariwisata Gempa
\end{tabular}

Untuk feature bigram, penerapan stemming justru meningkatkan akurasi dari model. Hal ini dikarenakan terdapat beberapa pasangan terms yang memiliki relevansi cukup tinggi pada suatu kategori dianggap berbeda karena berbeda imbuhan. Hal ini merupakan general phenomenon pada text behavior dimana suatu pasangan kata memiliki relevansi yang tinggi terhadap suatu dokumen terlepas dari ada atau tidaknya imbuhan. Oleh karena itu, penerapan stemming untuk feature bigram dapat meningkatkan bobot dari pasangan term yang merupakan feature penting untuk suatu kategori. Contoh pasangan term yang mengalami kenaikan bobot setelah dilakukan stemming dapat dilihat pada Tabel XVI.

TABLE XVI. FEATURE BIGRAM PENTING YANG MENGALAMI PENINGKATAN BOBOT SETELAH STEMMING.

\begin{tabular}{|c|c|c|}
\hline \multicolumn{2}{|c|}{ Feature } & \multirow{2}{*}{ Kategori } \\
\hline Sebelum stemming & Setelah stemming & \\
\hline $\begin{array}{c}\text { kementerian } \\
\text { keuangan } \\
(w=52.3059)\end{array}$ & $\begin{array}{l}\text { menteri uang } \\
(w=73.188)\end{array}$ & Ekonomi Gempa \\
\hline $\begin{array}{c}\text { kementerian } \\
\text { kesehatan } \\
(\mathrm{w}=82.44171)\end{array}$ & $\begin{array}{l}\text { menteri sehat } \\
(w=86.3875)\end{array}$ & Kesehatan Gempa \\
\hline $\begin{array}{c}\text { dapat menyebabkan } \\
(\mathrm{w}=65.531)\end{array}$ & $\begin{array}{l}\text { dapat sebab } \\
(w=68.8886)\end{array}$ & $\begin{array}{l}\text { Kesehatan Non- } \\
\text { gempa }\end{array}$ \\
\hline
\end{tabular}

Hasil yang didapatkan dari skema pengujian ini melalui 5-fold cross validation dapat dilihat pada Tabel XVIII.

TABLE XVII. HASIL PENGUJIAN DENGAN STEMMING DAN STOPWORDS.

\begin{tabular}{|c|c|c|c|c|}
\hline Jenis Feature & Precision & Recall & $\begin{array}{c}\text { F- } \\
\text { Measure }\end{array}$ & $\begin{array}{c}\text { Standar } \\
\text { Deviasi }\end{array}$ \\
\hline Unigram & $94.93 \%$ & $93.63 \%$ & $94.13 \%$ & $1.32 \%$ \\
\hline Bigram & $93.68 \%$ & $94.57 \%$ & $93.98 \%$ & $1.99 \%$ \\
\hline $\begin{array}{c}\text { Unigram dan } \\
\text { Bigram }\end{array}$ & $94.66 \%$ & $91.71 \%$ & $92.89 \%$ & $1.66 \%$ \\
\hline
\end{tabular}

\subsection{Pengujian dengan Stemming dan Stopwords Removal}

Pada skema pengujian ini, dilakukan stemming dan stopwords removal pada data training. Hasil training menggunakan seluruh dataset menghasilkan vocabulary dengan panjang 13033 untuk feature unigram dan 98154 untuk feature bigram. 10 feature dengan bobot tertinggi untuk masing-masing jenis feature dan kategori dapat dilihat pada Tabel XVIII, Tabel XIX, Tabel XX, dan Tabel XXI.

TABLE XVIII. FEATURE UNIGRAM DENGAN STEMMING DAN STOPWORDS REMOVAL PADA ARTIKEL GEMPA.

\begin{tabular}{|c|r|c|c|c|r|}
\hline \multicolumn{2}{|c|}{ Ekonomi Gempa } & \multicolumn{2}{c|}{ Kesehatan Gempa } & \multicolumn{2}{c|}{ Pariwisata Gempa } \\
\hline Feature & \multicolumn{1}{c|}{ Bobot } & Feature & Bobot & Feature & Bobot \\
\hline palu & 201.13 & korban & 231.91 & gili & 290.8 \\
\hline rp & 191.2 & sehat & 227.37 & lombok & 264.2 \\
\hline bank & 190.7 & gempa & 168.47 & gempa & 221.8 \\
\hline lombok & 176.1 & lombok & 150.31 & pariwisata & 211.2 \\
\hline bencana & 175.91 & palu & 149.35 & wisatawan & 203.8 \\
\hline
\end{tabular}

TABLE XIX. FEATURE UNIGRAM DENGAN STEMMING DAN STOPWORDS REMOVAL PADA ARTIKEL NON-GEMPA.

\begin{tabular}{|c|c|c|c|c|c|}
\hline \multicolumn{2}{|c|}{$\begin{array}{c}\text { Ekonomi Non- } \\
\text { gempa }\end{array}$} & $\begin{array}{c}\text { Kesehatan Non- } \\
\text { gempa }\end{array}$ & \multicolumn{2}{c|}{$\begin{array}{c}\text { Pariwisata Non- } \\
\text { gempa }\end{array}$} \\
\hline Feature & Bobot & Feature & Bobot & Feature & Bobot \\
\hline saham & 310.34 & jantung & 373.94 & pantai & 248.1 \\
\hline rp & 291.2 & sakit & 298.43 & wisata & 227.5 \\
\hline harga & 256.82 & kanker & 271.04 & gili & 227.3 \\
\hline banjir & 233.91 & serang & 249.51 & gunung & 220.5 \\
\hline tol & 225.15 & seks & 247.44 & unjung & 216.6 \\
\hline
\end{tabular}

TABLE XX. FEATURE BIGRAM DENGAN STEMMING DAN STOPWORDS REMOVAL PADA ARTIKEL GEMPA.

\begin{tabular}{|c|c|c|c|c|c|}
\hline \multicolumn{2}{|c|}{ Ekonomi Gempa } & \multicolumn{2}{c|}{ Kesehatan Gempa } & \multicolumn{2}{c|}{ Pariwisata Gempa } \\
\hline Feature & Bobot & Feature & Bobot & Feature & Bobot \\
\hline rp miliar & 157.18 & $\begin{array}{c}\text { korban } \\
\text { gempa }\end{array}$ & 123.9 & $\begin{array}{c}\text { gili } \\
\text { trawangan }\end{array}$ & 116.1 \\
\hline rp triliun & 88.87 & $\begin{array}{c}\text { rumah } \\
\text { sakit }\end{array}$ & 100.2 & $\begin{array}{c}\text { gunung } \\
\text { rinjani }\end{array}$ & 92.9 \\
\hline $\begin{array}{c}\text { sri } \\
\text { mulyani }\end{array}$ & 88.327 & $\begin{array}{c}\text { menteri } \\
\text { sehat }\end{array}$ & 86.39 & gili air & 90.98 \\
\hline rp juta & 77.739 & $\begin{array}{c}\text { lombok } \\
\text { utara }\end{array}$ & 84.71 & menteri & 73.52 \\
\hline $\begin{array}{c}\text { kantor } \\
\text { cabang }\end{array}$ & 74.912 & $\begin{array}{c}\text { rsud } \\
\text { tanjung }\end{array}$ & 76.6 & jalur daki & 65.41 \\
\hline
\end{tabular}

TABLE XXI. FEATURE BIGRAM DENGAN STEMMING DAN STOPWORDS REMOVAL PADA ARTIKEL NON-GEMPA.

\begin{tabular}{|c|c|c|c|c|c|}
\hline \multicolumn{2}{|c|}{$\begin{array}{c}\text { Ekonomi Non- } \\
\text { gempa }\end{array}$} & \multicolumn{2}{c|}{$\begin{array}{c}\text { Kesehatan Non- } \\
\text { gempa }\end{array}$} & \multicolumn{2}{c|}{$\begin{array}{c}\text { Pariwisata Non- } \\
\text { gempa }\end{array}$} \\
\hline $\begin{array}{c}\text { Feature } \\
\text { jalan } \\
\text { tol }\end{array}$ & Bobot & Feature & Bobot & Feature & Bobot \\
\hline $\begin{array}{c}\text { rp } \\
\text { triliun }\end{array}$ & 146.61 & $\begin{array}{c}\text { serang } \\
\text { jantung }\end{array}$ & 221.91 & $\begin{array}{c}\text { kompas } \\
\text { com }\end{array}$ & 108.7 \\
\hline $\begin{array}{c}\text { harga } \\
\text { rokok }\end{array}$ & 111.28 & $\begin{array}{c}\text { getah } \\
\text { bening }\end{array}$ & 81.83 & $\begin{array}{c}\text { gili } \\
\text { ranungani }\end{array}$ & 106.8 \\
\hline $\begin{array}{c}\text { rp ribu } \\
\text { rinjani }\end{array}$ & 92.328 & $\begin{array}{c}\text { kelenjar } \\
\text { getah }\end{array}$ & 79.683 & gili air & 90.98 \\
\hline $\begin{array}{c}\text { dollar } \\
\text { as }\end{array}$ & 82.62 & $\begin{array}{c}\text { paru } \\
\text { paru }\end{array}$ & 75.427 & $\begin{array}{c}\text { daki } \\
\text { gunung }\end{array}$ & 78.43 \\
\hline
\end{tabular}


Pada tabel yang telah disajikan, dapat dilihat beberapa feature yang telah dihilangkan dari pengujian tanpa penggunaan stemming maupun stopwords removal. Feature yang dihilangkan adalah stopwords dan feature-feature berimbuhan yang digabung menjadi satu feature yang berupa kata dasar. Untuk feature unigram, tidak terdapat perubahan bobot feature yang cukup besar untuk tiap kategori. Sehingga penerapan stemming bersamaan dengan stopwords removal tidak memiliki pengaruh yang cukup besar terhadap akurasi dari model.

Akan tetapi, penggunaan stemming bersamaan dengan stopwords removal pada feature bigram dapat meningkatkan akurasi secara signifikan dibandingkan dengan penerepan stopwords removal tanpa stemming. Hal ini dikarenakan suatu feature yang terdiri dari 2 kata yang sebenarnya tidak bersebelahan dikarenakan penghilangan stopwords memiliki bobot yang lebih tinggi ketika feature yang sama namun berbeda imbuhan dijadikan satu feature melalui tahap stemming. Proses ini tidak menghilangkan pelanggaran terhadap konsep bigram, tetapi dapat meningkatkan akurasi dari model dengan cukup signifikan.

Hasil yang didapatkan dari skema pengujian ini melalui 5-fold cross validation dapat dilihat pada Tabel XXI.

TABLE XXII. HASIL PENGUJIAN DENGAN STEMMING DAN STOPWORDS REMOVAL.

\begin{tabular}{|c|c|c|c|c|}
\hline Jenis Feature & Precision & Recall & $\begin{array}{c}\text { F- } \\
\text { Measure }\end{array}$ & $\begin{array}{c}\text { Standar } \\
\text { Deviasi }\end{array}$ \\
\hline Unigram & $94.22 \%$ & $95.15 \%$ & $94.54 \%$ & $1.66 \%$ \\
\hline Bigram & $83.27 \%$ & $88.00 \%$ & $83.73 \%$ & $2.62 \%$ \\
\hline Unigram dan Bigram & $95.12 \%$ & $95.47 \%$ & $95.20 \%$ & $1.58 \%$ \\
\hline
\end{tabular}

Pada Gambar 2, ukuran vocabulary yang didapatkan dari tiap jenis feature berbeda-beda satu sama lain. Feature unigram memiliki ukuran vocabulary jauh lebih kecil dibandingkan dengan feature bigram. Hal ini disebabkan oleh pasangan kata yang bervariasi dalam tiap dokumen. Ukuran vocabulary dari penggunaan feature unigram bersamaan dengan feature bigram sendiri merupakan jumlah dari ukuran 2 jenis feature tersebut. Selain itu, dapat dilihat juga penggunaan stemming dan stopwords removal juga dapat mengurangi ukuran dari vocabulary.

Pada Gambar 3, dapat dilihat bahwa penggunaan stemming mengurangi nilai $f$-measure dari pengujian menggunakan feature unigram. Hal ini juga berlaku pada pengujian yang menggunakan feature unigram sekaligus bigram dan menyertakan stopwords. Akan tetapi, nilai $f$-measure yang didapatkan pada pengujian dengan menggunakan stemming justru mengalami peningkatan pada feature bigram Nilai $f$-measure dari feature unigram sekaligus bigram yang tidak menyertakan stopwords juga mengalami peningkatan ketika dilakukan stemming.

Pada Gambar 3 juga dapat dilihat bahwa penghilangan stopwords dapat meningkatkan nilai $f$ measure untuk pengujian dengan feature unigram dan juga feature unigram sekaligus bigram. Akan tetapi, stopwords removal pada pengujian dengan feature bigram justru dapat mengurangi nilai $f$-measure secara signifikan.

\section{Penutup}

Berdasarkan hasil penelitian yang telah didapatkan, dapat disimpulkan bahwa:

1. Metode multimonial naïve Bayes dapat diterapkan pada kasus klasifikasi artikel dimana pada penilitian ini didapatkan akurasi yang cukup tinggi yaitu dengan nilai $f$-measure mencapai $95.20 \%$ dan standar deviasi sebesar $1.58 \%$ melalui pengujian dengan 5 perulangan 5 -fold cross validation.

2. Penggunaan stemming mengurangi akurasi pada pengujian dengan feature unigram karena terdapat kata berimbuhan yang merupakan feature unik dari suatu kategori.

3. Penggunaan stemming pada pengujian dengan feature bigram dapat meningkatkan akurasi dari percobaan. Hal ini merupakan general phenomenon pada text behavior dimana suatu pasangan kata memiliki relevansi yang tinggi terhadap dokumen terlepas dari imbuhan-nya.

4. Penggunaan stopwords removal pada feature bigram dapat menurunkan akurasi dari model secara signifikan karena hilangnya suatu kata dapat menghilangkan pasangan kata yang berkontribusi positif terhadap dokumen.

5. Pada penilitian ini, hasil pengujian terbaik didapatkan dengan menggunakan feature unigram sekaligus bigram dan dengan melewati tahap stemming dan stopwords removal. Sedangkan hasil pengujian dengan nilai $f$-measure terendah didapatkan dari pengujian dengan feature bigram yang tidak melewati tahap stemming tetapi melewati tahap stopwords removal.

Kemudian terdapat beberapa catatan saran untuk dapat diperbaiki serta dikembangkan pada penelitian serupa selanjutnya yaitu melakukan feature selection pada model dan menambah feature trigram dalam skema pengujian. 


\section{UCAPAN TERIMA KASIH}

Ucapan terima kasih diberikan kepada pakar ilmu komunikasi, Shinta Desiyana Fajarica, S.IP., M.Si., yang telah mengarahkan dalam pengumpulan data.

\section{DAFTAR PUSTAKa}

[1] N. Aziz, "Mengapa gempa terus terjadi di Indonesia?," BBC, 7 Agustus 2018. [Online]. Available: https://www.bbc.com. [Diakses 4 Desember 2018].

[2] F. Handayani and F. S. Pribadi, "Implementasi Algoritma Naive Bayes Classifier dalam Pengklasifikasian Teks Otomatis Pengaduan dan Pelaporan Masyarakat melalui Layanan Call Center 110," Jurnal Teknik Elektro, vol. 7, no. 1, pp. 19-24, 2015.

[3] T. Jo, "Text Mining : Concepts, Implementation, and Big Data Challenge", vol. 45, Cham: Springer International Publishing AG, 2019.

[4] C. D and P. R. H. S. Manning, Introduction to Information Retrieval, New York: Cambridge University Press, 2008.

[5] M. S. Islam, M. I. Fauzan P. P. N. and M. T. Pratama, "Penggunaan Naive Bayes Classifier untuk Pengelompokan Pesan Pada Ruang Percakapan Maya dalam Lingkungan Kemahasiswaan," Jurnal Computech \& Bisnis, vol. 11, no. 2, pp. 87-97, 2012.

[6] R. N. Devita, H. W. Herwanto and A. P. Wibawa, "Perbandingan Kinerja Metode Naive Bayes dan KNearest Neighbor untuk Klasifikasi Artikel Berbahasa Indonesia," Jurnal Teknologi Informasi dan IImu Komputer, vol. 5, no. 4, pp. 427-434, 2018.

[7] I. B. G. W. Putra, M. Sudarma and I. N. S. Kumara, "Klasifikasi Teks Bahasa Bali dengan Metode Supervised
Learning Naïve Bayes Classifier," Teknologi Elektro, vol. 15, no. 2, pp. 81-86, 2016.

[8] A. P. Wijaya and H. A. Santoso, "Naive Bayes Classification pada Klasifikasi Dokumen Untuk Identifikasi Konten EGovernment," Journal of Applied Intelligent System, vol. 1, no. 1, pp. 48-55, 2016.

[9] M. A. Ulfa, B. Irmawati and A. Y. Husodo, "Twitter Sentiment Analysis using Naive Bayes Classifier with Mutual Information Feature Selection," J-COSINE, vol. 2, no. 2, pp. 106-111, 2018.

[10] A. M. Kibriya, E. Frank, B. Pfahringer and G. Holmes, "Multinomial Naive Bayes for Text Categorization Revisited," in Australian Joint Conference on Artificial Intelligence, Cairns, 2004.

[11] A. Rahman, W. and A. Doewes, "Online News Classification Using Multinomial Naive Bayes," ITSMART: Jurnal Ilmiah Teknologi dan Informasi, vol. 6, no. 1, pp. 32-38, 2017.

[12] F. Tempola, M. Muhammad and A. Khairan, "Perbandingan Klasifikasi Antara Knn Dan Naive Bayes Pada Penentuan Status Gunung Berapi Dengan K-Fold Cross Validation," Jurnal Teknologi Informasi dan IImu Komputer, vol. 5, no. 5, pp. 577-584, 2018.

[13] M. S. H. Simarangkir, "Studi Perbandingan AlgoritmaAlgoritma Stemming untuk Dokumen Teks Bahasa Indonesia," Jurnal Inkofar, vol. 1, no. 1, pp. 40-46, 2017.

[14] H. R. Pramudita, "Penerapan Algoritma Stemming Nazief \& Adriani dan Similarity pada Penerimaan Judul Thesis," Jurnal IImiah DASI, vol. 15, no. 4, pp. 15-19, 2014. 